\title{
Keragaan Pertumbuhan dan Hasil Tanaman Jagung Manis terhadap Pemberian Dosis Pupuk Semi Organik pada Lahan Rawa Lebak
}

\author{
(Diversity of Growth and Yield Sweet Corn to Organic Semi Fertilizer \\ Dosage Granting on Lebak Wetland)
}

\author{
Ainor Ridha Saputera ${ }^{1}$ ), Mahdiannoor $\left.{ }^{2}\right)$ \& M. Gazali Habibi ${ }^{3)}$ \\ Program Studi Agroteknologi, Sekolah Tinggi Ilmu Pertanian Amuntai \\ 1)ainor_rs@gmail.com \\ ${ }^{2)}$ mahdi_186@yahoo.com \\ ${ }^{3)}$ gazalihbb@gmail.com
}

\begin{abstract}
ABSTRAK
Produksi jagung di Kabupaten Hulu Sungai Utara terbilang masih rendah dibandingkan dengan komoditas pangan yang lain karena lahan yang digunakan adalah rawa lebak. Permasalahan pada lahan rawa lebak adalah tingkat kesuburan tanah yang rendah. Salah satu solusi untuk meningkatkan keragaan pertumbuhan dan hasil tanaman jagung yaitu dengan menggunakan pupuk semi organik. Tujuan penelitian (i) mengetahui keragaan pertumbuhan dan hasil tanaman jagung manis terhadap pemberian dosis pupuk semi organik pada lahan rawa lebak (ii) mendapatkan dosis pupuk semi organik terbaik yang memperlihatkan keragaan pertumbuhan dan hasil tanaman jagung manis teroptimal pada lahan rawa lebak. Penelitian dilaksanakan di Desa Pandulangan Kecamatan Sungai Pandan Kabupaten Hulu Sungai Utara Provinsi Kalimantan Selatan, dilaksanakan pada bulan April Juni 2013, menggunakan Rancangan Acak Kelompok (RAK) faktor tunggal, dengan 5 taraf perlakuan yang terdiri dari : $m_{1}=38$ g.petak ${ }^{-1}, m_{2}=47,5$ g.petak ${ }^{-1}, m_{3}=57,0$ g.petak ${ }^{-1}, m_{4}=66,5$ g.petak ${ }^{-1}$ dan $m_{5}=76$ g.petak ${ }^{-1}$. Setiap perlakuan terdiri 4 ulangan sehingga terdapat 20 satuan percobaan. Peubah pengamatan yang diukur adalah tinggi tanaman, jumlah daun pertanaman, jumlah tongkol per petak, jumlah tongkol per tanaman, dan berat basah tongkol per tanaman pada umur 28, 35, 42 dan 49 HST. Hasil penelitian menunjukkan adanya keragaan pertumbuhan dan hasil tanaman jagung manis terhadap pemberian pupuk semi organik pada lahan rawa lebak dengan dosis pupuk semi organik terbaik adalah 57,0 g.petak ${ }^{-1}$ setara dengan $300 \mathrm{~kg} . \mathrm{ha}^{-1}\left(\mathrm{~m}_{3}\right)$.
\end{abstract}

Kata kunci : Jagung, semi organik, lahan, rawa lebak, dosis.

ABSTRACT

Maize production in Hulu Sungai Uatara Regency is still low compared to other food commodities because the land used is lebak wetland. The problem with lebak wetland is low soil fertility. One solution to improve the performance of growth and yield of corn plants is by using semi-organic fertilizers. The purpose of the study (i) was to determine the performance of growth and yield of sweet corn on doses of semi-organic fertilizer on swamp lebak (ii) to obtain the best dosage of semi-organic fertilizer that showed optimal growth and yield of sweet corn on lebak wetland. The study was carried out in the Pandulangan Village, Sungai Pandan Sub-District, Hulu Sungai Utara Regency, South Kalimantan Province, conducted in April - June 2013, using a single factor Randomized Group Design $(R G D)$, with 5 treatment levels with 5 levels of treatment consisting of: $m_{1}=38$ g.plot ${ }^{-1}, m_{2}=47.5 \mathrm{~g}$. plot $^{-1}, m_{3}=57.0 \mathrm{~g}$. plot $^{-1}, m_{4}=66.5 \mathrm{~g}$. plot $^{-1}$ and $m_{5}=76 \mathrm{~g}$. plot $^{-1}$. Each treatment consisted of 4 replications so that there were 20 experimental units. The results showed that the growth and yield of sweet corn on the application of semi-organic fertilizer on lebak wt land with the best dosage of semiorganic fertilizer was $57.0 \mathrm{~g}$. plot $^{-1}$ was equivalent to $300 \mathrm{~kg}^{.} \mathrm{ha}^{-1}\left(\mathrm{~m}_{3}\right)$.

Keywords: Corn, semi organic, land, lebak wetland, dosage.

\section{PENDAHULUAN}

Tanaman jagung merupakan suatu komoditas strategis dan bernilai ekonomis, serta mempunyai peluang untuk dikembangkan karena kedudukannya sebagai sumber utama karbohidrat dan 
protein setelah beras. Di samping itu jagung berperan sebagai pakan ternak, bahan baku industri dan rumah tangga. Semakin meningkatnya pertumbuhan laju penduduk dan meningkatnya juga kebutuhan pakan (Alam dan Nurhaeni, 2008).

Menurut Mayadewi (2007), jagung manis atau yang lebih dikenal dengan nama sweet corn mulai dikembangkan di Indonesia pada awal tahun 1980, diusahakan secara komersial dalam skala kecil untuk memenuhi kebutuhan hotel dan restoran. Jagung manis dapat tumbuh pada daerah beriklim sedang sampai beriklim tropis.

Produksi tanaman jagung di Kabupaten Hulu Sungai Utara terbilang masih rendah dibandingkan dengan komoditas pangan yang lain. Produksi jagung pada tahun 2008 yaitu 751 ton dengan luas panen 295 ha, tahun 2009 yaitu 1.648 ton dengan luas panen 616 ha, pada tahun 2010 yaitu 630 ton dengan luas panen 232 ha dan pada tahun 2011 yaitu 867 ton dengan luas panen 363 ha (Dinas Pertanian Tanaman Pangan dan Hortikultura HSU, 2012).

Tanah rawa lebak merupakan tanah yang terdapat pada lahan basah dan terdiri atas tanah-tanah basah. Dalam kondisi alami, tanah rawa lebak merupakan tanah yang selalu jenuh air atau tergenang sepanjang tahun atau dalam waktu yang lama, beberapa bulan dalam setahun (Ardi, et. al., 2006).

Potensi lahan rawa lebak di Indonesia mencapai 13,28 juta ha, terdiri dari rawa lebak dangkal seluas 4.167 juta ha, lebak tengahan seluas 6.075 juta ha, dan lebak dalam seluas 3.038 juta ha. Pemanfaatan lahan rawa lebak untuk usaha pertanian kedepan perlu mendapatkan perhatian yang lebih baik agar potensinya dapat dimanfaatkan secara optimal dan sumberdaya alamnya tetap terpelihara dengan baik (Ardi, et. al., 2006).

Lahan yang digunakan dalam penelitian ini adalah lahan rawa lebak yang berada di Desa Pandulangan Kecamatan Sungai Pandan Kabupaten Hulu Sungai Utara. Lahan rawa lebak tersebut mengandung unsur nitrogen yang rendah dengan nilai $0,11 \%$, fosfor sedang dengan nilai $29,193 \mathrm{mg} / 100 \mathrm{~g}$, kalium yang juga tergolong sedang dengan nilai 27,52 $\mathrm{mg} / 100 \mathrm{~g}$, dan tanah bersifat asam dengan pH 5,01 (Laboratorium Kimia, Fisika dan Biologi Tanah, 2012).

Permasalahan pada lahan rawa lebak tersebut adalah tingkat kesuburan tanah yang rendah. Salah satu solusi untuk meningkatkan keragaan pertumbuhan dan hasil tanaman jagung yaitu dengan menggunakan pupuk semi organik. Pupuk semi organik yang akan digunakan memiliki kandungan hara $\mathrm{N}$ yang sedang yaitu $1,90 \%, \mathrm{P}$ yang sedang yaitu $1,9 \%$ dan $\mathrm{K}$ yang sedang yaitu $1,6 \%$ (CV. Sinar Agung, 2013

Tanah di Indonesia paling banyak dijumpai adalah tanah asam, sehingga menimbulkan banyak persoalan pada tanaman, pada kondisi tersebut unsur hara sulit tersedia terutama $\mathrm{Ca}, \mathrm{Mg}, \mathrm{P}$, dan $\mathrm{Mo}$, serta mempengaruhi aktivitas organisme pengurai, sehingga tanaman menderita dan dampak terparahnya keracunan alumunium yang terlarut dalam tanah (CV. Sinar Agung, 2013).

Kelebihan pupuk semi organik yaitu mengandung unsur makro dan mikro, dilengkapi dengan formula Growth Regulators yang dapat memaksimalkan pertumbuhan dan perkembangan tanaman, ramah lingkungan dan mampu meningkatkan kesuburan tanah, mampu menetralisir sekaligus menjaga keasaman tanah, dan mampu meningkatkan produktivitas tanaman baik secara kualitas dan kuantitas (CV. Sinar Agung, 2013).

Pemberian pupuk semi organik pada tanaman jagung yaitu pemupukan susulan I (20 hari setelah tanam/HST) untuk jenis pupuk MekaGreen dan Urea sebanyak 100 $\mathrm{kg} / \mathrm{ha}^{-1}$, pemupukan susulan II (35 HST) sebanyak $150 \mathrm{~kg} \cdot \mathrm{ha}^{-1}$. Sehingga jumlah pupuk semi organik yang digunakan untuk tanaman jagung sebanyak $250 \mathrm{~kg} \cdot \mathrm{ha}^{-1}$ (CV. Sinar Agung, 2013).

Pemberian pupuk majemuk NPK menunjukkan adanya pengaruh nyata terhadap pertumbuhan dan hasil tanaman 
jagung pada lahan rawa lebak dengan dosis terbaik 300 kg.ha-1 (Rahmadani, 2012).

Tujuan penelitian (i) mengetahui keragaan pertumbuhan dan hasil tanaman jagung manis terhadap pemberian pupuk semi organik pada lahan rawa lebak, (ii) mengetahui dosis pupuk semi organik terbaik yang memperlihatkan keragaan pertumbuhan dan hasil tanaman jagung manis teroptimal pada lahan rawa lebak.

\section{METODE PENELITIAN}

Penelitian ini dilaksanakan di Desa Pandulangan Kecamatan Sungai Pandan Kabupaten Hulu Sungai Utara Provinsi Kalimantan Selatan. Penelitian dilaksanakan pada bulan April - Juni 2013. Bahan yang digunakan antara lain adalah : benih jagung Varietas Bonanza $2 \mathrm{~F}_{1}$, lahan rawa lebak, pupuk dasar urea, pupuk semi organik MekaGreen sebagai perlakuan, air dan pestisida alami. Alat yang di pakai adalah sebagai berikut : parang, cangkul, meteran, gembor, hand sprayer, timbangan, alat tulis dan kamera.

Percobaan ini menggunakan Rancangan Acak Kelompok (RAK) faktor tunggal. Faktor yang diteliti adalah perlakuan dosis pupuk semi organik (M) sebanyak 5 taraf yang terdiri dari : $\mathrm{m}_{1}=38$ g.petak ${ }^{-1}$ setara dengan $200 \mathrm{~kg} \cdot \mathrm{ha}^{-1}, \mathrm{~m}_{2}=$ 47,5 g.petak ${ }^{-1}$ setara dengan $250 \mathrm{~kg} \cdot \mathrm{ha}^{-1}$, $\mathrm{m}_{3}=57,0$ g.petak ${ }^{-1}$ setara dengan 300 kg.ha ${ }^{-1}, \mathrm{~m}_{4}=66,5$ g.petak ${ }^{-1}$ setara dengan $350 \mathrm{~kg} \cdot \mathrm{ha}^{-1}$ dan $\mathrm{m}_{5}=76$ g.petak ${ }^{-1}$ setara dengan $400 \mathrm{~kg} \cdot \mathrm{ha}^{-1}$. Perlakuan pemberian beberapa dosis pupuk semi organik terdapat 5 perlakuan dengan 4 ulangan, didapatkan 20 satuan percobaan.

Pelaksanaan percobaan terdiri dari penanaman, pemberian pupuk dasar, pemberian perlakuan, pemeliharaan dan pemanenan. Pengamatan yang dilakukan adalah mengukur tinggi tanaman dan jumlah daun per tanaman umur 28, 35, 42 dan 49 hari setelah tanam (HST), jumlah tongkol per petak, jumlah tongkol per tanaman dan berat basah tongkol per tanaman.

Analisis data yang dilakukan setelah data terkumpul, maka terlebih dahulu dilakukan uji kehomogenan ragam. Apabila data yang didapat tidak homogen, maka dilakukan transformasi supaya data homogen, untuk mengetahui berpengaruh atau tidaknya perlakuan terhadap pertumbuhan dan hasil tanaman jagung, maka dilakukan uji-F pada taraf nyata $5 \%$ dan $1 \%$, sedangkan untuk mengetahui perlakuan terbaik digunakan uji DMRT dengan taraf nyata $5 \%$.

\section{HASIL DAN PEMBAHASAN Hasil}

\section{Tinggi Tanaman}

Hasil analisis ragam menunjukkan bahwa pemberian perlakuan dosis pupuk semi organik berpengaruh nyata pada umur 28, 35, 42 dan 49 HST terhadap tinggi tanaman. Hasil uji beda rata-rata tinggi tanaman jagung pada umur 28, 35, 42 dan 49 HST terhadap perlakuan pupuk semi organik disajikan pada Tabel 1.

Tabel 1. Hasil uji beda rata-rata tinggi tanaman jagung pada umur 28, 35, 42 dan 49 HST terhadap pemberian perlakuan dosis pupuk semi organik

\begin{tabular}{ccccc}
\hline \multirow{2}{*}{ Perlakuan } & \multicolumn{4}{c}{ Rata-rata tinggi tanaman $(\mathrm{cm})$} \\
\cline { 2 - 5 } & $28 \mathrm{HST}$ & $35 \mathrm{HST}$ & $42 \mathrm{HST}$ & $49 \mathrm{HST}$ \\
\hline $\mathrm{m}_{1}$ & $70,00_{\mathrm{a}}$ & $86,75_{\mathrm{a}}$ & $92,37_{\mathrm{a}}$ & $97,00_{\mathrm{a}}$ \\
$\mathrm{m}_{2}$ & $72,62_{\mathrm{a}}$ & $95,00_{\mathrm{ab}}$ & $99,50_{\mathrm{ab}}$ & $107,25_{\mathrm{ab}}$ \\
$\mathrm{m}_{3}$ & $71,25_{\mathrm{a}}$ & $100,37_{\mathrm{abc}}$ & $108,25_{\mathrm{abc}}$ & $111,87_{\mathrm{abc}}$ \\
$\mathrm{m}_{4}$ & $81,25_{\mathrm{ab}}$ & $104,75_{\mathrm{bc}}$ & $109,12_{\mathrm{bc}}$ & $115,12_{\mathrm{bc}}$ \\
$\mathrm{m}_{5}$ & $95,87_{\mathrm{b}}$ & $113,12_{\mathrm{c}}$ & $122,00_{\mathrm{c}}$ & $113,12_{\mathrm{c}}$
\end{tabular}

Keterangan: Angka yang diikuti huruf subscrift yang sama pada kolom yang sama tidak berbeda menurut DMRT pada taraf uji 5\% 
Pada Tabel 1, tinggi tanaman umur 28 HST pada perlakuan $\mathrm{m}_{4}$ merupakan perlakuan terbaik yang tidak berbeda dengan perlakuan $\mathrm{m}_{5}$, tetapi berbeda dengan perlakuan $\mathrm{m}_{1}, \mathrm{~m}_{2}$ dan $\mathrm{m}_{3}$. Umur $35 \mathrm{HST}$ perlakuan $m_{3}$ merupakan perlakuan terbaik yang tidak berbeda dengan perlakuan $\mathrm{m}_{4}$ dan $\mathrm{m}_{5}$, tetapi berbeda dengan $\mathrm{m}_{1}$ dan $\mathrm{m}_{2}$. Pada umur 42 HST tinggi tanaman pada perlakuan $\mathrm{m}_{3}$ merupakan perlakuan terbaik yang tidak berbeda dengan perlakuan $\mathrm{m}_{4}$ dan $m_{5}$, tetapi berbeda dengan $m_{1}$ dan $m_{2}$.

\section{Jumlah Daun}

Hasil analisis ragam menunjukkan bahwa pemberian perlakuan dosis pupuk semi organik berpengaruh nyata terhadap jumlah daun umur 28, 35, 42 dan 49 HST. Hasil uji beda rata-rata jumlah daun tanaman jagung pada umur 28, 35, 42 dan 49 HST terhadap perlakuan pupuk semi organik disajikan pada Tabel 2.

Tabel 2. Hasil uji beda rata-rata jumlah daun tanaman jagung pada umur 28, 35, 42 dan 49 HST terhadap pemberian dosis pupuk semi organik

\begin{tabular}{ccccc}
\hline \multirow{2}{*}{ Perlakuan } & \multicolumn{4}{c}{ Rata-rata jumlah daun (helai) } \\
\cline { 2 - 5 } & $28 \mathrm{HST}$ & $35 \mathrm{HST}$ & $42 \mathrm{HST}$ & $49 \mathrm{HST}$ \\
\hline $\mathrm{m}_{1}$ & $7,50_{\mathrm{a}}$ & $7,62_{\mathrm{a}}$ & $7,75_{\mathrm{a}}$ & $7,87_{\mathrm{a}}$ \\
$\mathrm{m}_{2}$ & $7,62_{\mathrm{a}}$ & $8,25_{\mathrm{ab}}$ & $8,12_{\mathrm{ab}}$ & $8,12_{\mathrm{ab}}$ \\
$\mathrm{m}_{3}$ & $8,37_{\mathrm{ab}}$ & $8,50_{\mathrm{bc}}$ & $8,50_{\mathrm{abc}}$ & $8,50_{\mathrm{abc}}$ \\
$\mathrm{m}_{4}$ & $8,62_{\mathrm{ab}}$ & $8,62_{\mathrm{bc}}$ & $8,75_{\mathrm{bc}}$ & $8,87_{\mathrm{bc}}$ \\
$\mathrm{m}_{5}$ & $9,25_{\mathrm{b}}$ & $9,12_{\mathrm{c}}$ & $9,12_{\mathrm{c}}$ & $9,25_{\mathrm{c}}$ \\
\hline
\end{tabular}

Keterangan : Angka yang diikuti huruf subscrift yang sama pada kolom yang sama tidak berbeda menurut DMRT pada taraf uji 5\%

Berdasarkan Tabel 4, jumlah daun tanaman jagung umur 28 HST pada perlakuan $\mathrm{m}_{3}$ merupakan perlakuan terbaik yang tidak berbeda dengan perlakuan $\mathrm{m}_{4}$ dan $\mathrm{m}_{5}$ tetapi berbeda dengan perlakuan $\mathrm{m}_{1}$ dan $\mathrm{m}_{2}$. Umur 35 HST perlakuan $m_{3}$ juga merupakan perlakuan terbaik yang tidak berbeda dengan perlakuan $\mathrm{m}_{4}$ dan $\mathrm{m}_{5}$, tetapi berbeda dengan $m_{1}$ dan $m_{2}$. Pada umur 42 HST perlakuan $\mathrm{m}_{3}$ juga merupakan perlakuan terbaik yang tidak berbeda dengan perlakuan $\mathrm{m}_{4}$ dan $\mathrm{m}_{5}$, tetapi berbeda dengan perlakuan $m_{1}$ dan $m_{2}$.

\section{Jumlah Tongkol Per petak}

Berdasarkan hasil analisis ragam menunjukkan bahwa pemberian perlakuan dosis pupuk semi organik berpengaruh nyata pada terhadap jumlah tongkol per petak. Hasil uji beda rata-rata jumlah tongkol per petak tanaman jagung dapat dilihat pada Tabel 3.

Tabel 3. Hasil uji beda rata-rata jumlah tongkol per petak tanaman jagung terhadap pemberian dosis pupuk semi organik

\begin{tabular}{cc}
\hline Perlakuan & Rata-rata tongkol per petak (buah) \\
\hline $\mathrm{m}_{1}$ & $1,75_{\mathrm{a}}$ \\
$\mathrm{m}_{2}$ & $2,25_{\mathrm{a}}$ \\
$\mathrm{m}_{3}$ & $2,75_{\mathrm{ab}}$ \\
$\mathrm{m}_{4}$ & $3,00_{\mathrm{ab}}$ \\
$\mathrm{m}_{5}$ & $3,75_{\mathrm{b}}$
\end{tabular}

Keterangan : Angka yang diikuti huruf subscrift yang sama pada kolom yang sama tidak berbeda menurut DMRT pada taraf uji $5 \%$

Pada Tabel 3, jumlah tongkol per petak pada perlakuan $\mathrm{m}_{3} \quad(300 \quad \mathrm{~kg} \cdot \mathrm{ha}-1)$ merupakan perlakuan terbaik yang tidak berbeda dengan perlakuan $\mathrm{m}_{4}$ dan $\mathrm{m}_{5}$, tetapi berbeda dengan perlakuan $\mathrm{m}_{1}$ dan $\mathrm{m}_{2}$. 
Hasil analisis ragam menunjukkan bahwa dosis pupuk semi organik berpengaruh nyata terhadap jumlah tongkol per tanaman. Hasil uji beda rata-rata jumlah tongkol per tanaman jagung dapat dilihat pada Tabel 4.

Tabel 4. Hasil uji beda rata-rata jumlah tongkol per tanaman jagung terhadap pemberian dosis pupuk semi organik

\begin{tabular}{cc}
\hline Perlakuan & Rata-rata tongkol per tanaman (buah) \\
\hline $\mathrm{m}_{1}$ & $1,75_{\mathrm{a}}$ \\
$\mathrm{m}_{2}$ & $2,25_{\mathrm{a}}$ \\
$\mathrm{m}_{3}$ & $2,75_{\mathrm{ab}}$ \\
$\mathrm{m}_{4}$ & $3,00_{\mathrm{ab}}$ \\
$\mathrm{m}_{5}$ & $3,75_{\mathrm{b}}$
\end{tabular}

Keterangan : Angka yang diikuti huruf subscrift yang sama pada kolom yang sama tidak berbeda menurut DMRT pada taraf uji 5\%

Berdasarkan Tabel 4 perlakuan $\mathrm{m}_{3}$ merupakan perlakuan terbaik untuk peubah pengamatan jumlah tongkol per tanaman

\section{Berat Basah Tongkol Per tanaman}

Berdasarkan hasil analisis ragam menunjukkan bahwa pemberian perlakuan dosis pupuk semi organik berpengaruh yang tidak berbeda dengan perlakuan $\mathrm{m}_{1}$, $\mathrm{m}_{2}, \mathrm{~m}_{4}$ dan $\mathrm{m}_{5}$.

sangat nyata terhadap berat basah tongkol per tanaman. Hasil uji beda rata-rata berat basah tongkol per tanaman jagung dapat dilihat pada Tabel 5.

Tabel 5. Hasil uji beda rata-rata berat basah tongkol per tanaman jagung terhadap pemberian perlakuan dosis pupuk semi organik

\begin{tabular}{cc}
\hline Perlakuan & Rata-rata berat basah tongkol per tanaman $(\mathrm{g})$ \\
\hline $\mathrm{m}_{1}$ & $200_{\mathrm{a}}$ \\
$\mathrm{m}_{2}$ & $258_{\mathrm{a}}$ \\
$\mathrm{m}_{3}$ & $293_{\mathrm{abc}}$ \\
$\mathrm{m}_{4}$ & $327_{\mathrm{bc}}$ \\
$\mathrm{m}_{5}$ & $385_{\mathrm{b}}$
\end{tabular}

Keterangan : Angka yang diikuti huruf subscrift yang sama pada kolom yang sama tidak berbeda menurut DMRT pada taraf uji $5 \%$

Dari Tabel 5 dapat dilihat pada peubah pengamatan berat basah tongkol per tanaman perlakuan $\mathrm{m}_{3}$ merupakan

\section{Pembahasan}

Hasil penelitian menunjukkan bahwa perlakuan pemberian dosis pupuk semi organik memberikan pengaruh yang nyata terhadap peubah yang diamati seperti tinggi dan jumlah daun tanaman jagung manis umur $28 \mathrm{HST}, 35 \mathrm{HST}$, $42 \mathrm{HST}$, dan 49 HST, jumlah tongkol per petak, jumlah perlakuan terbaik yang tidak berbeda dengan perlakuan $\mathrm{m}_{4}$ dan $\mathrm{m}_{5}$, tetapi berbeda nyata dengan perlakuan $\mathrm{m}_{1}$ dan $\mathrm{m}_{2}$.

tongkol per tanaman, dan berat basah tongkol per tanaman.

Menurut hasil analisis Laboratorium Kimia, Fisika dan Biologi Tanah (2012), lahan rawa lebak di Desa Pandulangan Kecamatan Sungai Pandan Kabupaten Hulu Sungai Utara mengandung unsur nitrogen yang rendah dengan nilai $0,11 \%$, fosfor sedang dengan nilai 29,193 mg.100g-1, kalium yang juga tergolong sedang dengan 
nilai 27,52 mg.100g-1, dan $\mathrm{pH}$ tanah yang tergolong masam dengan nilai 5,01. Sedangkan pada Fe-Larut tinggi dengan nilai 30,25 ppm. Dengan nilai NPK yang tergolong rendah, proses terjadinya pertumbuhan tinggi tanaman mengalami kekurangan unsur hara. Tetapi kekurangan unsur hara pada tanah ini dipenuhi oleh unsur hara NPK dari pupuk. Menurut CV. Sinar Agung (2012), menunjukkan bahwa pupuk semi organik yang digunakan mengandung $\mathrm{N}$ yang sedang yaitu $1,90 \%$, $\mathrm{P}_{2} \mathrm{O}$ yang sedang yaitu $1,90 \%$, dan $\mathrm{K}_{2} \mathrm{O}$ yang sedang yaitu 1,60\%. Demikian juga dengan unsur $\mathrm{MgO}$ dan $\mathrm{CaO}$ pada pupuk yang membantu proses fotosintesis, dan unsur hara B yang berperan dalam pembentukan dinding sel dan pembentukan titik tumbuh (Tyaras, 2011). Hal ini terlihat dari hasil analisis pupuk semi oganik yang menunjukkan $\mathrm{Ca}$ organik yang sangat tinggi yaitu 28,61 \% dengan unsur $\mathrm{N}, \mathrm{P}$ dan $\mathrm{K}$ yang tergolong sangat sedang.

Pertumbuhan tanaman dipengaruhi oleh ketersediaan unsur hara yang dibutuhkan dalam jumlah yang cukup, yang dapat diperoleh dari penambahan unsur hara dari luar. Karena pada kedua fase pertumbuhan vegetatif primer dan sekunder pada pemberian pupuk semi organik memberikan pengaruh, artinya kandungan hara yang ada pada tanah dan pupuk mampu mencukupi kebutuhan hara tanaman, hal ini karena unsur $\mathrm{N}$ yang dimiliki oleh pupuk semi organik, berfungsi sebagai tanaman diperlukan untuk pembentukan atau pertumbuhan bagian-bagian vegetatif tanaman dan berperan penting dalam pembentukan klorofil untuk meningkatkan proses fotosintesis yang ada pada gilirannya akan meningkatkan pertumbuhan tanaman seperti batang, akar dan daun (Millya, 2007).

Tinggi tanaman merupakan salah satu indikator pertumbuhan. Indikator pertumbuhan diperlukan untuk melakukan pendekatan pada nilai pertumbuhan tanaman. Pada peubah tinggi tanaman perlakuan pupuk semi organik memberikan pengaruh nyata, karena kandungan pupuk semi organik digunakan untuk menyusun berbagai substansi didalam tanaman, senyawa nitrogen digunakan tanaman untuk membentuk senyawa asam amino yang akan diubah menjadi protein (Millya, 2007).

Pada fase vegetatif dari tinggi tanaman yang telah melewati umur pertumbuhan awal dimana tanaman sudah membentuk cabang mengabsorbsi $\mathrm{N}$ lebih cepat dan lebih banyak sehingga nampak pertumbuhannya lebih signifikan (Kunianto, 2010). Hal ini terlihat pada pemberian perlakuan pupuk semi organik yang mana unsur $\mathrm{N}$ mampu tersedia bagi tanaman. Kandungan $\mathrm{N}$ yang terdapat pada pupuk semi organik memiliki kriteria yang sedang yaitu $1,90 \%$. Fosfor berperan dalam pembentukan bibit tanaman. Defisiensi $\mathrm{P}$ dapat menekan jumlah bunga dan menunda inisiasi pembungaan. Sedangkan fungsi $\mathrm{K}$ dapat mempercepat metabolisme unsur nitrogen.

Pemberian $\mathrm{N}$ pada tanaman akan mendorong pertumbuhan organ-organ yang berkaitan dengan fotosintesis yaitu daun. Tanaman yang cukup mendapat suplai $\mathrm{N}$ akan membentuk daun yang memiliki helaian lebih luas dengan kandungan klorofil yang lebih tinggi, sehingga tanaman mampu menghasilkan karbohidrat/asimilat dalam jumlah yang cukup untuk pertumbuhan vegetatif (Wijaya, 2008 dalam Mahdiannoor, 2012).

Analisis ragam menunjukkan bahwa perlakuan pupuk semi organik berpengaruh nyata pada jumlah daun. Menurut Millya (2007), nitrogen membentuk senyawa penting seperti klorofil, asam nukleat dan enzim, karena itu nitrogen dibutuhkan dalam jumlah yang relatif besar pada setiap tahap pertumbuhan vegetatif yaitu pembentukan tunas atau perkembangan batang dan daun. Ketersediaan unsur $\mathrm{N}$ dalam jumlah yang cukup dalam jaringan tanaman berpengaruh terhadap aktifitas 
fotosintesis melalui pembentukan klorofil. Oleh karena itu apabila kandungan klorofil di dalam daun cukup tersedia, maka fotosintat yang dihasilkan melalui proses fotosintesis juga mengalami peningkatan. Fungsi Fosfor (P) merupakan senyawa penyusun jaringan tanaman seperti asam nukleat, fosfolipida, dan fitin. $\mathrm{P}$ diperlukan untuk pembentukan primordia bunga dan organ tanaman untuk reproduksi (Rosmarkam dan Yuwono, 2002).

Unsur $\mathrm{K}$ sangat berperan dalam mengaktifasi enzim-enzim yang berperan dalam metabolisme dan biosintetis. Kandungan $\mathrm{N}$ yang terdapat pada pupuk semi organik memiliki kriteria yang sedang yaitu $1,90 \%$. K juga sangat berperan dalam menjaga tekanan osmosis dan turgor sel. Apabila kandungan $\mathrm{K}$ di dalam tanaman turun, tekanan turgor sel-sel tanaman termasuk sel penutup stomata berkurang dan sebagai akibatnya stomata akan menutup. Defisiensi K menyebabkan kerusakan kloroplas dan mitokondria sel tanaman, sehingga tanaman yang mengalami defisiensi $\mathrm{K}$ tidak mampu melakukan fotosintesis secara optimal. Akibatnya tanaman akan tidak mampu menghasilkan fotosintat untuk mendukung pertumbuhan normal (Wijaya, 2008 dalam Mahdiannoor, 2012).

Berdasarkan hasil analisis ragam menunjukkan bahwa perlakuan berpengaruh nyata pada jumlah tongkol per petak dan per tanaman. Dengan nilai P dan $\mathrm{K}$ yang tergolong sedang, proses terjadinya pertambahan jumlah tongkol per petak dan per tanaman mengalami kekurangan unsur hara. Namun karena unsur P pada pupuk semi organik dapat tersedia bagi tanaman dapat menutupi kekurangan tersebut. Menurut Koentjoro dan Dewanti (1998), menjelaskan proses pembentukan buah disamping dipengaruhi oleh proses penyerbukan juga dipengaruhi oleh tersedianya unsur hara yang cukup. Disamping fosfat tersedianya nitrogen yang cukup juga sangat diperlukan untuk pembentukan bunga, buah serta memperbaiki kualitas buah. Adanya pemberian pupuk semi organik memberikan pengaruh nyata terhadap peubah jumlah tongkol per petak dan jumlah tongkol per tanaman dipengaruhi penurunan kadar karbohidrat dalam tanaman sehingga menunjukkan adanya kompetisi antara penyusunan karbohidrat (pati, sukrosa dan polifruktosa) dan penyusunan asam amino. Sedangkan unsur K dalam hal ini berfungsi untuk mempengaruhi susunan dan mengedarkan karbohidrat di dalam tanah, mempercepat metabolisme unsur nitrogen dan mencegah bunga dan buah agar tidak mudah gugur (Tyaras, 2011).

Dari hasil analisis ragam terlihat bahwa pemberian pupuk semi organik menunjukkan pengaruh nyata terhadap berat basah tongkol per tanaman. Hal ini diduga karena perakaran tanaman dapat menyerap langsung unsur hara yang diberikan oleh pupuk semi organik. Menurut Marsono dan Sigit (2001), mengatakan bahwa fosfor berfungsi merangsang pertumbuhan dan perkembangan akar, sebagai bahan dasar protien, membantu respirasi dan asimilasi, membantu proses pemasakan biji dan buah. Kekurangan unsur fosfor akan menyebabkan ukuran tongkol menjadi kecil dan bentuknya tidak normal.

Pada fase generatif pupuk semi organik mampu menambah ketersediaan unsur $\mathrm{P}$ dan K pada tanaman. Penambahan hara N, $\mathrm{P}, \mathrm{K}$ bagi tanaman dari hasil mineralisasi oleh mikroorganisme, transformasi oleh mikroorganisme dari suatu unsur pada bahan organik menjadi anorganik melalui mineralisasi, menjadikan unsur hara tersedia bagi tanaman. .

Nitrogen (N) sebagai bahan pembentuk kholofil daun sangat diperlukan untuk memacu proses fotosintesis daun. Selain itu $\mathrm{N}$ juga sebagai pembentuk senyawa asamasam amino dan protein untuk pertumbuhan tanaman. Fosfat (P) sangat diperlukan untuk energi pertumbuhan (ATP) termasuk 
pembentukkan biji, sementara $\mathrm{K}$ memacu translokasi hasil fotosintesis dari daun kebagian lain tanaman dan berperan untuk pembentukan karbohidrat tanaman (Syafruddin dan Zubachtirodin, 2010). Menurut Mayadewi (2007), peningkatan berat segar tongkol berhubungan erat dengan besarnya fotosintat yang ditranslokasikan ke bagian tongkol. Semakin besar fotosintat yang ditranslokasikan ke tongkol maka semakin meningkat pula berat segar tongkol. Fotosintat tersebut sangat menentuka hasil biji karena sebagian fotosintat ditumbun dalam biji. Selama periode pengisian biji terjadi peningkatan akumulasi bahan kering dan kekurangan hara pada periode ini akan menyebabkan biji tidak berkembang penuh.

\section{KESIMPULAN}

Adanya keragaan pertumbuhan dan hasil tanaman jagung manis terhadap pemberian pupuk semi organik pada lahan rawa lebak dengan perlakuan dosis pupuk semi organik terbaik yang memperlihatkan keragaan pertumbuhan dan hasil tanaman jagung manis teroptimal pada lahan rawa lebak yaitu pada dosis 57,0 g.per petak $^{-1}$ setara dengan $300 \mathrm{~kg} \cdot \mathrm{ha}^{-1}\left(\mathrm{~m}_{3}\right)$.

\section{DAFTAR PUSTAKA}

Ardi, S., Kurnia, U., Mamat H.S., Hartatik, W., Setyorini, D. 2006. Karekteristikdan pengelolaan lahan rawa. Balai Penelitian dan Pengembangan Pertanian. Bogor.

Alam dan Nurhaeni. 2008. Komposisi kimia dan sifat fungsional pati jagung berbagai varietas yang diekstrak dengan pelarut natrium bikarbonat. Jurnal Agroland Vol.15 (2).

CV. Sinar Agung. 2013. Pupuk Semi Organik Dan Ramah Lingkungan. Jawa Timur.
Dinas Pertanian Tanaman Pangan dan Hortikultura. 2012. Laporan Dinas Pertanian Tanaman Pangan dan Hortikultura. Kabupaten Hulu Sungai Utara.

Koentjoro, Y \& D. Dewanti. 1998. Aplikasi pupuk nitrogen dan pemberian kadar air tanah yang berbeda terhadap pertumbuhan dan hasil tanaman cabai besar (Capsicum annum L). J. Penelitian Mapeta: 1(1).

Laboratorium Kimia, Fisika dan Biologi Tanah. 2012. Hasil Analisis Contoh Tanah. Fakultas

Pertanian Universitas Lambung Mangkurat. Banjarbaru.

Mahdiannoor. 2012. Efektivitas pemberian Trichoderma spp. Dan dosis pupuk kandang kotoran ayam pada lahan rawa lebak terhadap pertumbuhan dan hasil tanaman kacang panjang (Vigna sinensis L.). Ziraa'ah Vol. 33 (1).

Marsono dan Sigit, P. 2001. Pupuk Akar. Penebar Swadaya. Jakarta.

Mayadewi, N. N. A. 2007. Pengaruh jenis pupuk kandang dan jarak tanam terhadap pertumbuhan gulma dan hasil tanaman jagung manis. Jurnal Agritrop Vol. 26 (4).

Millya, A. P. 2007. Pengaruh waktu pembenaman orok-orok (Crotalaria juncea L.) dan dosis pupuk Urea pada pertumbuhan dan hasil tanaman jagung (Zea mays L.) Skripsi. Universitas Brawijaya. Malang.

Rahmadani, A. 2012. Respon pertumbuhan dan hasil tanaman jagung (Zea mays L.) terhadap pemberian pupuk majemuk NPK pada lahan rawa lebak. Skripsi. Sekolah Tinggi Ilmu Pertanian Amuntai. 
Rosmarkam, A. dan Nasih Widya Yuwono.

2002. Ilmu Kesuburan Tanah. Kanisius. Yogyakarta

Harjadi, S. S. 1993. Pengantar Agronomi. Gramedia. Jakarta.

Syafruddin. dan Zubachtirodin. 2010. Penggunaan pupuk NPK majemuk 20:10:10 pada tanaman jagung. Balai Penelitian Serealia. Sulawesi Selatan.

Tyaras. 2011. Jenis dan Fungsi Pupuk. http://tyras.files.wordpress.com. Diakses pada tanggal 20 Maret 2 013.

Warisno. 1998. Seri Budidaya Jagung Hibrida. Kanisius. Yogyakarta. 